\title{
PENGUATAN MANAJEMEN KURIKULUM TERINTEGRASI PADA MADRASAH DI LINGKUNGAN PESANTREN
}

\author{
Mohammad Zaini \\ Dosen FTIK IAIN Jember \\ mohzainimm@gmail.com
}

\begin{abstract}
Good integrated curriculum planning affects the implementation of curriculum in a good boarding school environment. The impact has a positive nuance for the development of curriculum management in Madrasah. The purpose of this research is to reveal: How to plan integrated curriculum on Madrasah in the pesantren environment in improving the quality of existing teachers. The study used a qualitative approach with multi-case design. Data validity collection and verification techniques. The results showed that (1) Integrated curriculum management in Madrasah in the boarding school needs to coordinate so that the curriculum is in accordance with the needs in three research locations, (2) The principal activities at the Madrasah And teachers can provide information to convey activity materials to students (3) The involvement of the principal in curriculum planning in the institution of boarding schools can exist if supported by local and national subjects. The conclusion of this study as follows (1) can improve teacher's professional and quality of education, (2) can improve the professionalism of teachers and students by the guidance on the new curriculum, (3) can meet the needs of society.
\end{abstract}

Keywords: Management, Curriculum, Madrasas, Islamic Boarding Schools

\section{PENDAHULUAN}

Arus perubahan yang semakin cepat dan berjalan secara linier mengikuti akselerasi kehidupan dunia pendidikan yang berpengaruh pada kurikulum terintegrasi sekarang ini meniscayakan terbentuknya tata kehidupan sosial dan struktur masyarakat modern yang di identifikasikan sebagai antithesis masyarakat tradisional (conservative sosiety), sekalipun masih banyak pakar pendidikan yang mengatakan bahwa perubahan ini terjadi secara non linier, tidak berkesinambungan (discontinous) dan tidak dapat diramalkan (unpredictable) tegasnya, kesemua premis itu menggambarkan kekhawatiran dunia akan kekurangsiapan kita dan sekaligus merupakan dorongan untuk mempersiapkan diri untuk berdialog dengan alam global artinya kita perlu mempertimbangkan. The Road stop here; where we go next. ${ }^{1}$

Sebagaimana dikatakan Dhofier keberadaan pesantren yang tetap bisa survive sampai sekarang tentu menjadi kebanggaan tersendiri bagi ummat Islam. Di tengah arus globalisasi, individualisme, dan pola hidup materialistik yang kian mengental, pesantren masih konsisten

${ }^{1}$ M. Afzalur Rahim, toward a theory of managing Organizational conflict, The International Journal of Conflict Management, 2002, Vol. 13, No. 3, pp. 206-235

Falasifa, Vol. 11 Nomor 1 Maret 2020 | 79 
menyuguhkan kitab kuning dan sistem pendidikan yang oleh sebagian orang di anggap tradisional, pengajaran kitab-kitab kuning (klasik) adalah salah satu elemen dasar dari tradisi pesantren di samping kyai, pondok, masjid, dan santri. ${ }^{2}$

Sedangkan Yasmadi mengatakan bahwa "Doktrin-doktrin dalam kitab kuning, yang senantiasa merujuk Al-Qur'an dan Sunnah Nabi sebagai sumber utama, merupakan salah satu roh yang menjiwai kehidupan pesantren. Seluruh sisi kehidupan pesantren bersifat religusteosentris, hal ini di sebabkan karena faktor kyai yang memainkan peran cukup sentral dalam sebuah pondok pesantren, sehingga semua aktivitas pendidikan di pandang sebagai ibadah kepada Allah. Aktivitas belajar, misalnya, bukan hanya di posisikan sebagai media (alat), tetapi sekaligus sebagai tujuan. Karena itu proses belajar-mengajar di pesantren sering kali tidak memperhitungkan waktu, strategi dan metode yang lebih kontekstual dengan perkembangan zaman. $^{3}$

Padahal, seiring dengan pergeseran zaman, santri membutuhkan formalitas seperti ijazah serta penguasaan bidang keahlian (keterampilan) tertentu. Di dunia modern santri tidak cukup hanya berbekal nilai dan norma moral saja, tetapi perlu pula di lengkapi dengan keahlian/skill yang relevan dengan kebutuhan dunia kerja modern.

Sehubungan dengan itu, Undang-undang nomor 20 tahun 2003 tentang Sistem Pendidikan Nasional pasal 3, menyatakan sebagai berikut:

Pendidikan nasional berfungsi mengembangkan kemampuan membentuk watak serta peradaban bangsa yang bermartabat dalam rangka mencerdaskan kehidupan bangsa, bertujuan untuk berkembangnya potensi peserta didik agar menjadi manusia yang beriman dan sertakwa kepada Tuhan Yang Maha Esa, berakhlak mulia, sehat, berilmu, cakap, kreatif, mandiri, dan menjadi warga negara yang demokratis serta sertanggung jawab. ${ }^{4}$

Sistem pendidikan nasional diharapkan mampu meningkatkan kecerdasan kehidupan bangsa dengan cara menjamin peningkatan mutu pendidikan, pemerataan kesempatan memperoleh pendidikan, relevansi pendidikan dengan kebutuhan pembangunan, dan efisiensi manajemen pendidikan untuk menghadapi tantangan dan tuntutan perubahan kehidupan lokal,

${ }^{2}$ Dhofier, Z 1995. Tradition and Change in Indonesian Islamic Education. Jakarta: Office of Religious Research and Development, Ministry of Religious Affairs of the Republica Indonesia.

3 Yasmadi, Modernisasi Pesantren (Kritik Nurcholis Madjid Terhadap Pendidikan Islam Tradisional). Jakarta: Ciputat Press, 2002.

4 Kementerian Sekretaris Negara. 1974. Undang-undang No. 5 Tahun 1974.

80 | Falasifa, Vol. 11 Nomor 1 Maret 2020 
nasional, dan global. Pendidikan yang bermutu, merata, dan relevan dapat berdampak ganda, yaitu menghasilkan sumber daya manusia (SDM) yang mampu bersaing dengan bangsa-bangsa lain, dan memperlancar pembangunan di sektor lain.

Ditinjau dari sistem pendidikan, kurikulum dan pembelajaran mempunyai kedudukan yang sangat penting dan strategis dalam keseluruhan proses pendidikan. Rasiyo menyatakan berikut ini.

Jika difungsikan secara tepat dan optimal, kurikulum sesungguhnya dapat menjadi salah satu pemicu strategis perbaikan dan pembaharuan, bahkan peningkatan mutu pendidikan khususnya mutu proses dan hasil pembelajaran atau pemelajaran. Dikatakan demikian karena ia merupakan perangkat cetak biru (blue print) yang berisi seperangkat pengaturan pembelajaran atau pemelajaran yang bersistem dan berstruktur yang menjadi acuan dan pedoman kerja dalam pembelajaran (instruction) dan pemelajaran (learning). Oleh karena itu, setiap dilakukan upaya perbaikan dan pembaharuan pendidikan di Indonesia (persekolahan), kurikulum selalu menjadi pusat perhatian dan mengalami perubahan. ${ }^{5}$

Di Indonesia telah terjadi beberapa kali perubahan kurikulum dalam upaya memperbaiki mutu pendidikan. Secara berturut-turut kurikulum yang baru memperbaiki kurikulum sebelumnya, yaitu dari Kurikulum 1947 yang memperbaiki Kurikulum jaman penjajahan Jepang, Kurikulum 1949, Kurikulum 1958, Kurikulum 1962 atau Kurikulum 1964, Kurikulum 1968, Kurikulum 1975, Kurikulum 1984, Kurikulum 1994 dengan Suplemen Kurikulum 1999, Kurikulum 2004 atau Kurikulum Berbasis Kompetensi, dan Kurikulum Tingkat Satuan Pendidikan yang mulai diberlakukan pada tahun pelajaran 2007/2008 dan kurikulum K.13. Menurut Supriadi, berdasarkan pengalaman selama ini terungkap bahwa letak kelemahan kurikulum di Indonesia terutama pada bagaimana kurikulum tersebut diimplementasikan secara sungguh-sungguh sehingga memberikan nilai tambah yang nyata bagi peningkatan mutu pendidikan.

Kurikulum berfungsi untuk memberi arah segala bentuk proses pendidikan kepada pencapaian tujuan-tujuan pendidikan. Kurikulum merupakan perangkat lunak yang memberi arah dan menentukan kualitas dan kuantitas produk pendidikan. Sedangkan proses kegiatan pendidikan di sekolah berpusat pada kegiatan pembelajaran. Bafadal menyatakan "kegiatan

5 Rasiyo (2005). Kebijakan Desentralisasi Manajemen Pendidikan Pada Era Otonomi Daerah,Surabaya:Program Doktor Ilmu Adminitrasi,Universitas 17 Agustus 1945, 215.

81 | Falasifa, Vol. 11 Nomor 1 Maret 2020 
belajar mengajar merupakan inti dari keseluruhan program pendidikan di sekolah". ${ }^{6}$ Kegiatan belajar-mengajar adalah kegiatan untuk penyampaian kurikulum dalam proses pembelajaran.'Sagala menyatakan “fokus kegiatan pembelajaran di sekolah adalah interaksi pendidik dan peserta didik dalam mempelajari suatu materi pelajaran yang telah tersusun dalam suatu kurikulum."7

Dengan demikian, untuk memperbaiki mutu pendidikan perlu ditekankan pada perbaikan manajemen kurikulum di sekolah yang manajemen kurikulum dan pembelajarannya baik diasumsikan dapat meningkatkan prestasi belajar peserta didiknya. Adanya sekolah yang mampu di satu pihak, dan ada sekolah yang kurang mampu di pihak lain, dalam menghasilkan lulusan yang berprestasi menunjukkan keragaman kemampuan dalam mengelola kurikulum, SDM dan sumber daya lainnya dalam kegiatan proses pembelajaran. Proses kegiatan manajemen yang berkaitan dengan kurikulum dan pembelajaran disekolah, meliputi perencanaan, pelaksanaan, dan evaluasi. ${ }^{8}$

Dalam UU Nomor 20 tahun 2003 tentang Sistem Pendidikan Nasional disebutkan:

"Kurikulum pada semua jenjang dan jenis pendidikan dikembangkan dengan prinsip diversifikasi sesuai dengan satuan pendidikan, potensi daerah, dan peserta didik" (Bab X, pasal 36 ayat (2). Pengembangan kurikulum secara berdiversifikasi dimaksudkan untuk memungkinkan penyesuaian program pendidikan pada satuan pendidikan dengan kondisi dan kekhasan potensi yang ada di daerah. Pemerintah (pusat) hanya meletakkan kerangka dasar dan struktur kurikulum pendidikan dasar dan menengah. Sedangkan pengembangan kurikulum berdasarkan standar nasional, kerangka dasar, dan struktur kurikulum sesuai dengan relevansinya diserahkan kepada sekolah bersama komite sekolah di bawah koordinasi dan supervisi Dinas Pendidikan Kabupaten/Kota (UU No. 20/2003 pasal 38 ayat 2; PP nomor 19/2005 pasal 31 ayat 2). Pemberlakuan kebijakan pemerintah yang hanya menetapkan standar isi untuk disusun Kurikulum Tingkat Satuan Pendidikan (KTSP) lebih menuntut kemampuan kepala sekolah dan guru dalam mengelola atau mengembangkan kurikulum dan pembelajaran di sekolah dibanding Kurikulum 1994 atau sebelumnya, yang lebih banyak diatur dari pusat (Supriadi, 2004, Permen Dikbud 22/2006).

Kepala sekolah dan guru bersama komite sekolah diberi peluang mengambil prakarsa

${ }^{6}$ Bafadah Ibrahim, Peningkatan Manajemen Mutu Sekolah Dasar: dari sentralisasai menuji desentralisasai, Jakarta, Bumi Aksara, 2003.

7 Anwar, Qomari. dan Syaiful, Sagala. 2004. Profesi Jabatan Kependidikan dan Guru Sebagai Upaya Menjamin Kualitas Pembelajaran. Jakarta: Uhamka Press.

${ }^{8}$ Bafadah Ibrahim, Peningkatan Manajemen Mutu ... Jakarta, Bumi Aksara, 2003.

${ }^{9}$ Peraturan Menteri Pendidikan Nasional Republik Indonesia Nomor 22 tahun 2006 tentangStandar Isi untuk Satuan Pendidikan Dasar dan Menengah, Kanwil Departemen Agama Provinsi Jawa Timur.

82 | Falasifa, Vol. 11 Nomor 1 Maret 2020 
secara kreatif dalam menjabarkan atau menyusun kurikulum untuk meningkatkan kesesuaian (relevansi), tujuan, isi, dan organisasi penyelenggaraan program-program pembelajaran sesuai dengan kebutuhan dan keadaan lingkungan. Kebutuhan untuk meningkatkan kemampuan personel sekolah, khususnya kepala sekolah dan guru, dalam memperbaiki manajemen kurikulum semakin besar dan mendesak seiring dengan pergeseran pola manajemen pendidikan nasional dari sentralisasi menujudesentralisasi dengan penerapan Manajemen Berbasis Sekolah (MBS).

Pendidikan berperan sangat penting dalam keseluruhan aspek kehidupan manusia, sebab pendidikan berpengaruh langsung kepada kepribadian ummat manusia. Pendidikan sangat menentukan terhadap model manusia yang dihasilkannya. Kurikulum sebagai rancangan pendidikan, mempunyai kedudukan sentral; menentukan kegiatan dan hasil pendidikan. Penyusunannya memerlukan fondasi yang kuat, didasarkan atas hasil pemikiran dan penelitian yang mendalam. Kurikulum yang lemah akan menghasilkan manusia yang lemah pula.

Sehubungan dengan itu, kajian tentang manajemen kurikulum terintegrasi pada sekolah/madrasah, terutama pada sekolah/madarasah di lingkungan pesantren yang terbukti menghasilkan output yang bermutu, menjadi penting bagi implementasi kurikulum terintegrasi pada madrasah di lingkungan pesantren, mengingat begitu padatnya kegiatan proses pembelajaran di lingkungan pesantren sehingga beban pelajaran yang harus diikuti oleh peserta didik di madrasah (sekolah di lingkungan Kementerian Agama) terutama yang berada di lingkungan pesantren menjadi sangat berat, karena disamping harus mengikuti proses pembelajaran di madrasah mereka harus juga mengikuti proses pembelajaran di pesantren hingga larut malam menyebabkan ketercapain hasil pembelajaran menjadi tidak optimal dan hal inilah yang ditengarai menyebabkan mutu hasil pendidikan madrasah menjadi kurang baik dibandingkan dengan mutu pendidikan sekolah oleh karena itu menjadi begitu penting bagi warga pengelola madrasah agar mempertimbangkan untuk dapat mengimplementasikan kurikulum terintegrasi pada madrasah di lingkungan pesantren sebagaimana ketiga madrasah terpilih yang menjadi subyek penelitian yaitu tiga madrasah Aliyah swasta di lingkungan pesantren yang dinilai mampu mengelola kurikulum terintegrasi pada madrasah di lingkungan pesantren oleh stakeholders, yaitu madarasah Aliyah Al-Mawaddah Coper-Jetis Ponorogo, madrasah Aliyah Unggulan Amanatul Ummah Siwalankerto Utara, Surabaya dan madrasah 
Aliyah Nurul Jadid Paiton Probolinggo.

Ketiga madrasah tersebut melakukan penyempurnaan kurikulum pembelajarannya sesuai dengan kebutuhan dan tujuan serta visi misi masing-masing, sehingga pada pelaksanaannya mempunyai kekhasan dan ciri yang berbeda dan tidak sama dengan kebanyakan sekolah/madrasah lain yang setingkat atau bahkan sesama sekolah/madrasah di lingkungan pesantren, seperti MA Al-Mawaddah pesantren Putri Coper Jetis Ponorogo, letak geografis madrasah Aliyah Al-Mawaddah terletak di Desa Coper Kecamatan Jetis Kabupaten Ponorogo sekitar $\pm 25 \mathrm{KM}$ dari Pusat Kota Kabupaten Ponorogo melaksanakan kurikulum terintegrasi dengan mengintegrasikan/ menyatukan pelajaran agama (Al-Qur'an-al Hadist, Akidah Akhlak, Fikih dan sejarah kebudayaan Islam) plus Bahasa Arab diintegrasikan dengan kurikulum pesantren/ ma'had (tafsir, Ulumul Qur'an, Ullumul Hadist, Fiqh, Ushul Fiqh, Nahwu, sharaf, Arudh, Balaghah dan Tauhid, akhlaq) dan mengajarkannya di Ma'had, artinya setiap matapelajaran yang temanya sama tersebut dan sudah diajarkan di pesantren tidak lagi diajarkan di madrasah serta diajarkan semuanya dengan pengantar Bahasa Arab sehingga outputnya dapat menguasai materi mata pelajaran sekaligus menguasai bahasa arabnya, sistem penilain dan ujiannya juga dilakukan di salah satu antara sekolah atau pesantren.

Sebagaimana dikatakan Oleh Ka. MA Utd. Ustuhori, semua materi pelajaran Agama (Negara) diajarkan di ma'had dan tidak diajarkan di madarasah dan penilaianpun dilakukan ma'had atau madrasah (H.W.01.1.01.05.01.11) begitu juga kurikulum terintegrasi di MA Unggulan Amanatul Ummah Siwalankerto Surabaya MA. Unggulan PP Amanatul Ummah adalah Madrasah yang beralamatkan di Jl. Siwalankerto Utara 56 Wonocolo Surabaya, yang siswa-siswinya terdiri dari santriwan-santriwati Pondok Pesantren Amanatul Ummah. MA Unggulan berdiri mulai tahun 2001 yaitu setelah 3 tahun berdirinya MTs. MA Unggulan PP Amanatul Ummah merupakan kelanjutan MTs. Unggulan Amanatul Ummah dalam menampung alumninya, agar proses yang unggul dapat berlanjut yang pada gilirannya dapat mengantarkan siswa-siswinya untuk melanjutkan kuliah di PTN-PTN terbaik dan pada jurusanjurusan yang favorit. Dan terakreditasi A pada tanggal 08 Desember 2005. Sementara sebelumnya yaitu pada tanggal 10 Mei 2004 telah meraih Qoror (Penetapan di samakan dengan Aliyah Al-Azhar Mesir). 
Selanjutnya setelah di Surabaya berdiri SNBI (Sekolah Nasional Bertaraf Intrnasional) yaitu SMA Negeri 05 Surabaya pada 2005-2006, maka MA. Unggulan Amanatul Ummah segera melakukan Konsultasi dan komunikasi dengan SMAN 05 Surabaya dan dengan perwakilan dari Cambridge untuk menjajaki apakah MA unggulan Amanatul Ummah bisa menyelenggarakan MNBI (Madrasah Nasional Bertaraf Internasional) agar tidak tertinggal oleh sekolah dibawah naungan Diknas. Hasilnya MA unggulan Amanatul Ummah mendirikan MNBI 2006-2007 dengan mengambil lokasi di daerah sejuk berjarak satu jam perjalanan dari Surabaya, yang kemudian berubah nama menjadi MBI dan pada 07 April 2007 dilaksanakan peletakan batu pertama untuk gedung baru MBI yang dilakukan langsung oleh Bapak Direktur Mapenda Depag RI (sekarang kementerian Agama RI) Dr. H. Firdaus M. Pd hampir sama dengan MA Al-Mawaddah, dikatakan oleh Ka. MA Ustad Mashudi sebagai berikut.

Pelajaran agama sesuai dengan kurikulum Kementerian Agama (Al-Qur'an-al Hadist, Akidah Akhlak, Fikih dan sejarah kebudayaan Islam) plus bahasa Arab diintegrasikan dengan kurikulum pesantren/ma'had (tafsir, Ulumul Qur'an, Ullumul Hadist, Fiqh, Ushul Fiqh, Nahwu, sharaf, Arudh, Balaghah dan Tauhid, akhlaq) diajarkan sore hari di ma'had akan tetapi secara administrasi kurkulum itu masih tercantum dalam kurikulum madrasah dan khusus untuk beberapa materi mata pelajaran agama tertentu gurunya adalah Native speaker, pengantarnya Berbahasa Arab guru pengajarnya berasal dari Universitas Al-Ashar Cairo.(P1/A/Al-Mawad/190320/09.00-11.00 wita)

Mungkin agak sedikit berbeda apa yang dilakukan MA Nurul Jadid, Paiton Probolinggo, guna menghasilkan output yang bermutu maka dimadrasah ini memberlakukan kurikulum terintegrasi sebagaimana dijelaskan oleh Ka. MA, Dr. KH. Maltuf berikut ini.

Pelaksanaan kurikulum terintegrasi diberlakukan terhadap materi pelajaran Agama (AlQur'an-al Hadist, Akidah Akhlak, Fikih dan sejarah kebudayaan Islam) secara keseluruhan diajarkan di Madrasah dengan berpedoman pada kurikulum Ma'had/pesantren yang bernama Furudul Ainiyah (pedoman kompetensi Dasar dan standart kompetensi lulusan pesantren) sedangkan Ma'had hanya melakukan pendalaman dengan menggunakan kajian Kitab Klasike/ kitab kuning, dan melakukan praktek ibadah terhadap materi Pelajaran agama yang memerlukan praktek, seperti wudhu dan sholat. (P1/A/Al-Mawad /190320/09.00-11.00 wita).

\section{Metode Penelitian}

Penelitian ini dilakukan selama 9 bulan di tiga Kabupaten se-Jawa Timur. Pada bulan pertama dilakukan obeservasi dengan menggunakan pendekatan kualitatif naturalistik memiliki 
karakteristik natural setting fenomenologis penelitian yang bersifat natural. ${ }^{10}$ dan rancangan penelitian multikasus (comparative and contrasted). Kehadiran peneliti instrument kunci (key instrument) teknik pengumpulan data dengan melakukan analisis wawancara, pengamatan, dan dokumen, Sumber data penelitian kualitatif sebagaimana dinyatakan Arikunto dapat berupa orang (person), tempat (place), dan simbol (purer). ${ }^{11}$ Sedangkan menurut Spradley menunjuk pada tiga kategori, yakni pelaku (actor), aktivitas (activity), dan tempat (place). ${ }^{12}$ Oleh karena itu analisis data dalam penelitian ini dilakukan ketika proses penelitian masih berlangsung (on going process) dan analisis pada saat berakhirnya kegiatan penelitian untuk selanjutnya dibuat laporan. Meskipun demikian tahapan analisis dapat dilakukan terhadap data hasil studi pendahuluan untuk menentukan fokus penelitian yang masih bersifat sementara, dan dikembangkan setelah peneliti memulai penelitian.

Dalam penelitian ini, tolak ukur kesahihan dan kepercayaan data tentang manajemen Kurikulum terintegrasi antara madrasah dengan pesantren, digunakan kriteria seperti dianjurkan Lincoln \& Guba, yaitu; (1) kredibilitas, (2) transferabilitas, (3) dependalibilitas, dan (4) konfirmabilitas. Namun dalam penelitian ini hanya digunakan tiga, dari empat kriteria tersebut yaitu: (1) kredibilitas, (2) dependabilitas, dan (3) konfirmabilitas. ${ }^{13}$

\section{HASIL DAN PEMBAHASAN}

\section{Temuan Penelitian pada Kasus I}

Temuan penelitian pada kasus I MA Al-Mawaddah di Kabupaten Ponorogo disajikan berdasarkan urutan fokus penelitian yaitu proses perencanaan Kurikulum terintegrasi antara madrasah dan pesantren, implementasi kurikulum antara madrasah dan pesantren, evaluasi kurikulum terintegrasi antara madrasah dan pesantren, serta implikasi kurikulum terintegrasi antara madrasah dan pesantren MA Al-Mawaddah di Kabupaten Ponorogo. Dari hasil temuan penelitian berdasarkan penyusunan KTSP di MA Al-Mawaddah sekurang-kurangnya berisi tentang. (1) KTSP dikembangkan dengan mengacu pada standar nasional pendidikan dan

\footnotetext{
${ }^{10}$ Nasution, 1996. MetodePenelitianNaturalistik Kualitatif. Bandung :Tarsito.

${ }^{11}$ Arikunto. 1990. Manajemen Penelitian. Jakarta: Rineka Cipta.

${ }^{12}$ Miles, B. \& Huberman, 1992 Analisis Data Kualitatf. (Terjemahan Tjetjep Rohendi Rohidi). Jakarta: Penerbit Universitas Indonesia, 1992.

${ }^{13}$ Guba, E.G \& Lincoln Y.S, 1981, Effektif Evaluation. Improving The Usefulness Of Evaluations Result Through Responsive And NaturalisticApproaches. Jassey-Bass Inc. Publisher.

86 | Falasifa, Vol. 11 Nomor 1 Maret 2020
} 
mencapai tujuan pendidikan nasional, (2) Kesesuaian KTSP dengan kekhasan, kondisi dan potensi daerah, sosial budaya masyarakat, kebutuhan dan potensi madrasah dan peserta didik menjadi pendukung penggunaan kurikulum terintegrasi, (3) Prasyarat keberhasilan penyelenggaraan pendidikan antara madrasah dengan pesantren, (4) KTSP mempertimbangkan kebutuhan masyarakat sekolah dan tantangan global. Pembinaan kurikulum terintegrasi terhadap MA Al-Mawaddah dengan bertujuan untuk mengakomodasi interaksi siswa dengan kurikulum yang baru, interaksi siswa dengan guru melalui berbagai kurikulum yang ada, dan interaksi antar siswa melalui beragam kegiatan pembelajaran melalui proses belajar mengajar di pesantren, dengan berbagai sumber belajar sebagai satu kesatuan utuh dalam sistem pembelajaran di pesantren, diharapkan siswa dapat melakukan proses belajar yang optimal dengan hasil yang memuaskan. Perencanaan kurikulum terintegrasi yang sudah berjalan selama ini menunjukan kemajuan yang sangat luar biasa jika dibandikan dengan penggunaan kurikulum yang lama, sehingga kolaborasi kurikulum terintegrasi memiliki implikasi praktis bagi siswa di antaranya: a) siswa yang ada di madrasah memiliki intensitas belajar yang tinggi terhadap pelaksanaan kurikulum terintegrasi dibandikan dengan hari-hari biasa, b) pengasuh pesantren yang ada di sekolah lebih mudah memanage dalam mewujudkan penyelenggaraan kurikulum terintegrasi c) kondisi siswa merespon kurikulum yang baru lebih elegan, sehingga sangat memungkinkan untuk belajar yang lebih serius, sehingga upaya pengembangan kurikulum dipesantren lebih baik dan peningkatan mutu siswa lebih berkualitas.

\section{Temuan Penelitian Pada Kasus II}

Temuan penelitian pada kasus II MA Unggulan Amanatul Ummah Surabaya disajikan berdasarkan urutan fokus penelitian yaitu proses perencanaan kurikulum terintegrasi antara madrasah dan pesantren, implementasi kurikulum antara madrasah dan pesantren, evaluasi kurikulum terintegrasi antara madrasah dan pesantren, serta implikasikurikulum terintegrasi antara madrasah dan pesantren MA Unggulan Amantul Ummah Surabaya.

Temuan hasil yang terteliti dari kasus II ini mendapatkan keunggulan dari segi kurikulum terintegrasi, maka salah satu karakteristik dari MA unggulan Amantul Ummah Surabaya adalah adanya sinergi antara guru dengan guru, siswa dengan siswa,siswa dengan guru yang begitu kuat sehingga manajemen kurikulum antara madrasah dengan pesantren menjadi lebih baik. Untuk menjembatani kondisi tersebut, maka MA Unggulan Amanatul Ummah menawarkan berbagai 
ragam bantuan belajar bagi siswa sebagai komplemen dari tuntutan belajar mandiri di pesantren. Layanan bantuan belajar itu diberikan dalam rangka membantu siswa memahami dan mendalami mata pelajaran agama dan matapelajaran umum serta membantu siswa belajar lebih proaktif, dapat di lihat pada gambar 1 berikut.

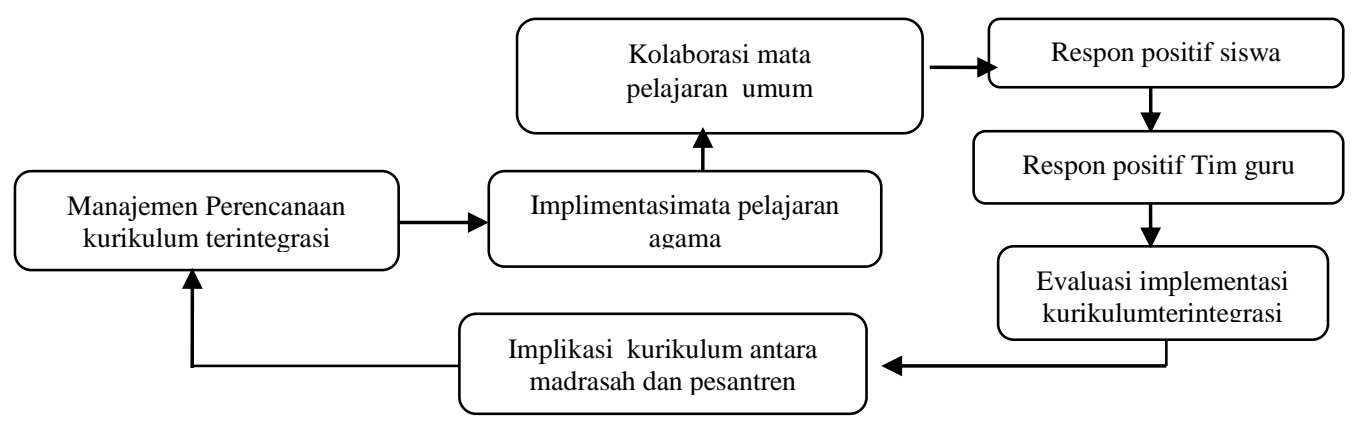

Gambar 1. Alur Integrasi Kurikulum Madrasah dengan Pesantren

Gambar diatas menunjukkan bahwa hubungan antara tim guru sebagai pengguna kurikulum, dengan siswa sebagai obyek kurikulum yang terintegrasi tidak bisa di pisahkan antara satu dengan yang lain memiliki pengaruh yang saling bergantungan (korelasi) yang positif karena ada kenyataan dan harapan. Karena memiliki korelasi yang tinggi sehingga akan membawa dampak positif terhadap kemajuan antara madrasah dengan pesantren Unggulan Amanatul Ummah pada tataran implementasi kurikulum teringtrasi. Ada pula anggapan bahwa tidak selalu mendapatkan perhatian dan dukungan yang positif dari beberapa guru yang ada di Amanatul Ummah karena mereka memiliki beragam pemahaman yang sulit di mengerti. Fenomena tersebut merupakan hal yang wajar karena secara khusus memiliki pengaruh pada sarana maupun fasilitas pendukung pelaksanaan pendidikan yang ada, bentuk kerjasama dengan Kemenag termasuk sistem manajemen berbasis sekolah yang digulirkan kepala wilayah setempat yang berbeda, di samping setiap daerah memiliki kultur bahkan karakter yang berbeda. Terkait dengan hal tersebut karena memang ada syarat penentuan kelayakan kelas dalam pelaksanaan kurikulum terintegrasi di MA Amanatul Ummah sebagai syarat penentuan kelayakan kelas dan fasilitas lain tersebut yang digunakan guru-guru harus memenuhi : a) guru bisa memberikan rasa nyaman bagi siswa, b) minimal guru juga sebagai pengajar berkualitas yang digunakan di lingkup MA Unggulan Amanatul Ummah Surabaya, c) penerangan kurikulum sesuai dengan waktu yang cukup tersedia, d) ventilasi udara yang memadai, e) 
tempat ibadah yang representatif, f) tempat parkir kendaraan guru, g) ada kantin yang sehat bagi siswa, h) ada keamananan yang cukup, dan i) ruangan guru yang ber-ac, j) siswa dan guru yang hadir tepat waktu.

\section{Temuan Penelitian Pada Kasus III}

Temuan penelitian pada kasus III Nurul Jadid Paiton Probolinggo disajikan berdasarkan urutan fokus penelitian yaitu proses manajemen kurikulum terintegrasi antara madrasah dan pesantren MA Nurul Jadid Paiton Probolinggo. Sebagai lembaga pendidikan islam yang memiliki satuan pedoman pendidikan kurikulum terintegrasi, maka salah satu karakteristik dari MA Nurul Jadid adalah adanya kebersamaan antara guru dan siswa dalam proses pembelajaran serta adanya sosialisasi kurikulum terintegrasi secara oriantit antara siswa dengan tim guru saling membutuhkan. Untuk menjembatani kondisi tersebut, maka MA Nurul Jadid menawarkan berbagai ragam kurikulum yang ada bagi siswa sebagai komplemen dari tuntutan kegiatan belajar mengajar. Ragam kurikulum yang tersedia bagi setiap siswa diberikan dalam rangka membantu siswa memahami dan mendalami materi mata pelajaran islam dan mata pelajar umum serta membantu siswa tersebut tanpak pada gambar 2 berikut.

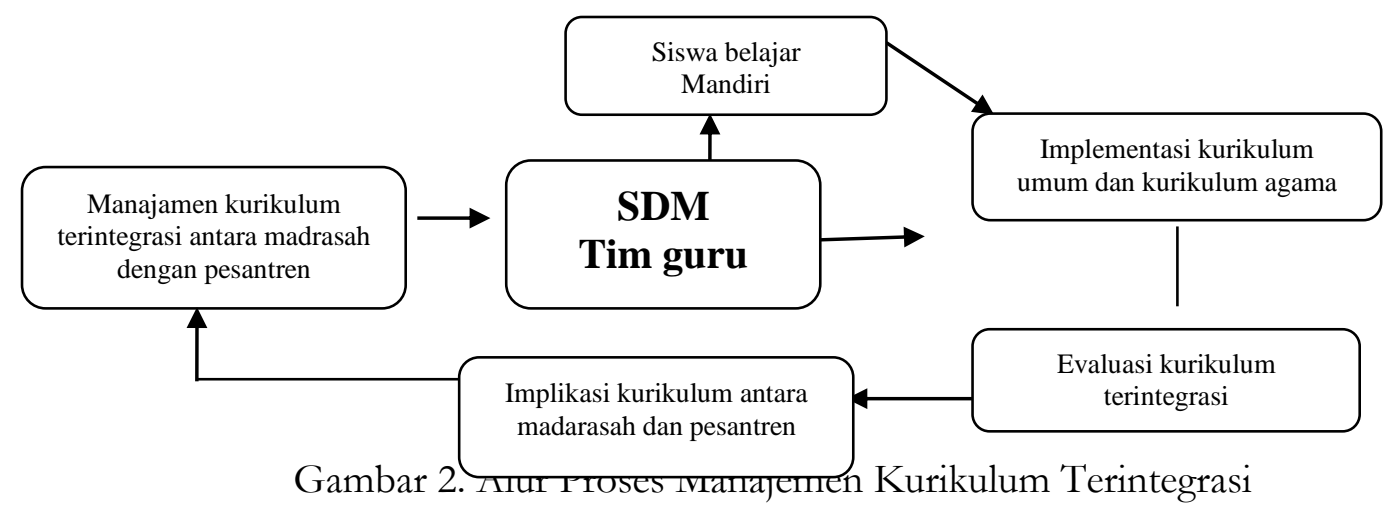

Pada gambar 2 alur manajemen kurikulum terintegrasi tersebut saling berhubungan tidak bisa di pisahkan antara satu dengan yang lain. Hal ini menunjukkan bahwa kurikulum di MA Nurul Jadid Paiton Probolinggo para pengasuh pesantren sangat antusias terhadap penyelenggaraan kurikulum terintegrasi ini. Hal tersebut dapat diketahui dari sejumlah fenomena baik fenomena integrasi dari guru maupun yang bersifat fasilitas fisik bagi siswa. Bagi pengasuh pondok pesantren, kegiatan pengembangan kurikulum terintegrasi bukan merupakan pekerjaan yang muda dilaksanakan, tetapi dijadikan pekerjaan rutin sehingga ditangani secara profesional.

89 | Falasifa, Vol. 11 Nomor 1 Maret 2020 
Beberapa fenomena yang dimaksud antara lain: a) guru hadir tepat waktu, b) siswa hadir disekolah tepat waktu sehingga kecenderungan semakin baik, c) buku pelajaran yang dibagikan pada saat pembelajaran sebagai penunjang semakin berkualitas, sementara Nurul Jadid Paiton Probolinggo telah menyediakan semua sarana yang ada disekolah sehingga dapat digunakan seoptimal mungkin. Berdasarkan hasil wawancara di lapangan data penelitian tersebut menunjukkan bahwa ketiga lokasi terdapat kebersamaan yang tertata dan fenomena masalah yang berbeda. Linearitas tersebut terletak pada konsep proses perencanaan kurikulum terintegrasi, implementasi, evaluasi dan implikasi kurikulum antara madrasah dan pesantren sebagai bentuk implementasi kurikulum terhadap layanan prima kepada siswa.

\section{Temuan Penelitian Lintas Kasus}

Berdasarkan pengumpulan data penelitian, maka untuk memperoleh temuan akhir sebagai temuan penelitian dilakukan dengan menformulasikan temuan dari ketiga kasus dan untuk mempermudah analisis masing-masing temuan ketiga kasus dapat dilihat pada tabel di bawah ini.

Tabel 1.

Analisis data Lintas Kasus Manajemen Kurikulum Terintegrasi pada Madrasah di lingkungan

Pesantren (MA Al-Mawaddah, MA Unggulan Amanatul Ummah, MA Nurul Jadid)

\begin{tabular}{|c|l|l|l|l|}
\hline \multirow{2}{*}{ Sub fokus } & $\begin{array}{c}\text { Temuan penelitian } \\
\text { di MA Al- } \\
\text { Mawaddah }\end{array}$ & $\begin{array}{c}\text { Temuan } \\
\text { penelitian di MA } \\
\text { Unggulan } \\
\text { Amanatul } \\
\text { Ummah }\end{array}$ & $\begin{array}{c}\text { Temuan } \\
\text { penelitian di } \\
\text { MA Nurul } \\
\text { Jadid }\end{array}$ & $\begin{array}{c}\text { Temuan } \\
\text { Penelitian }\end{array}$ \\
\hline $\begin{array}{c}\text { 1.Perencan } \\
\text { aan }\end{array}$ & $\begin{array}{l}\text { 1. Tanggapan atau } \\
\text { reaksi guru }\end{array}$ & $\begin{array}{c}\text { 1.Respon guru } \\
\text { MA Unggulan }\end{array}$ & $\begin{array}{c}\text { 1. Respon } \\
\text { positif guru }\end{array}$ & • Sebetulnya \\
proses \\
terinterg & terhadap & Amanatul & MA Nurul & Pada \\
asi & kelaksanaan & Ummah & Jadid & desain \\
antara & terintegrasi antara & terhadap & terhadap & mata \\
madrsah & madrasah dengan & kurikulum & manajemen & pelajaran \\
dengan & pesantren yang & terintegrasi & terintegrasi \\
pesantre & digunakan oleh & antara & antara & didak \\
na Al- & madrasah & madrasah & secara \\
& Mawaddah & terpisah, \\
& sebagai berikut. & pesantren & dengan & akan tetapi \\
& pesantren & mata \\
\hline
\end{tabular}

90 | Falasifa, Vol. 11 Nomor 1 Maret 2020 
Penguatan Manajemen Kurikulum Terintegrasi...

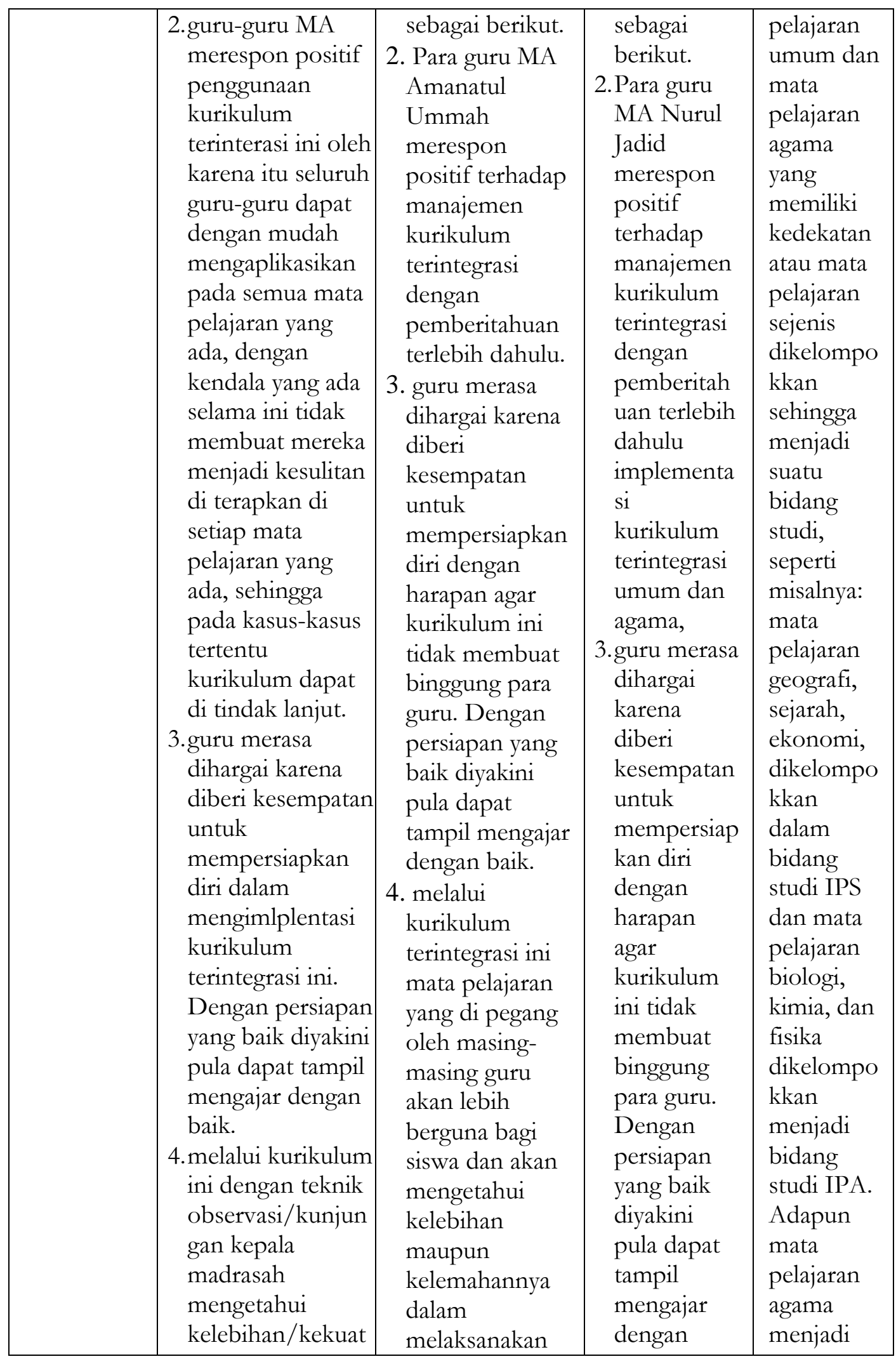

91 | Falasifa, Vol. 11 Nomor 1 Maret 2020 


\begin{tabular}{|c|c|c|c|}
\hline $\begin{array}{l}\text { an maupun } \\
\text { kelemahan/kekur } \\
\text { angannya dalam } \\
\text { melak-sanakan } \\
\text { proses belajar } \\
\text { mengajar dengan } \\
\text { mengintegrasikan } \\
\text { kurikulum yang } \\
\text { ada dapat segera } \\
\text { menemukan } \\
\text { solusi. } \\
\text { 5.guru-guru di MA } \\
\text { Al-Mawaddah } \\
\text { memberikan } \\
\text { respon positif } \\
\text { terhadap } \\
\text { implementasi } \\
\text { kurikulum ini } \\
\text { sehingga di MA } \\
\text { Al-Mawaddah } \\
\text { bisa lebih unggul } \\
\text { siswanya dengan } \\
\text { sekolah yang lain, } \\
\text { dapat di gunakan } \\
\text { oleh waka } \\
\text { kurikulum pada } \\
\text { saat melakukan } \\
\text { balikan PBM } \\
\text { setelah observasi. } \\
\text { 6.Guru-guru MA } \\
\text { Al-Mawaddah } \\
\text { memberikan } \\
\text { tanggapan yang } \\
\text { positif terhadap } \\
\text { rapat guru-guru } \\
\text { ketika proses } \\
\text { pelaksanaan } \\
\text { kurikulum } \\
\text { terintegrasi karena } \\
\text { mereka } \\
\text { mempunyai } \\
\text { kesempatan } \\
\text { menyatakan } \\
\text { pendapat atau } \\
\text { permasalahan, }\end{array}$ & $\begin{array}{l}\text { proses belajar } \\
\text { mengajar, dapat } \\
\text { memberikan } \\
\text { tanggapan } \\
\text { positif terhadap } \\
\text { teknik } \\
\text { percakapan } \\
\text { individual yang } \\
\text { digunakan oleh } \\
\text { kepala } \\
\text { madrasah pada } \\
\text { saat melakukan } \\
\text { balikan } \\
\text { pelaksanaan/im } \\
\text { plementasi } \\
\text { kurikulum ini. } \\
\text { 5.guru } \\
\text { memberikan } \\
\text { tanggapan } \\
\text { positif terhadap } \\
\text { teknik supervisi } \\
\text { rapat guru-guru } \\
\text { karena mereka } \\
\text { mempunyai } \\
\text { kesempatan } \\
\text { lebih bebas } \\
\text { untuk } \\
\text { menyatakan } \\
\text { pendapat/perm } \\
\text { asalahan } \\
\text { sehubungan } \\
\text { dengan PBM, } \\
\text { bertukar pikiran } \\
\text { untuk mencari } \\
\text { solusi atas } \\
\text { permasalahan } \\
\text { yang dihadapi. } \\
\text { 6.secara } \\
\text { proposional } \\
\text { merupakan } \\
\text { lembaga yang } \\
\text { memiliki } \\
\text { karakteristik } \\
\text { yang berbeda } \\
\text { dari jumlah }\end{array}$ & $\begin{array}{l}\text { baik, } \\
\text { 4.melalui } \\
\text { kurikulum } \\
\text { terintegrasi } \\
\text { ini dengan } \\
\text { teknik } \\
\text { observasi/ } \\
\text { kunjungan } \\
\text { kelas kepala } \\
\text { sekolah } \\
\text { mengetahui } \\
\text { kelebihan } \\
\text { guru } \\
\text { maupun } \\
\text { kelemahann } \\
\text { ya dalam } \\
\text { melaksanak } \\
\text { an proses } \\
\text { belajar } \\
\text { mengajar, } \\
\text { dapat } \\
\text { memberika } \\
\text { n tanggapan } \\
\text { positif } \\
\text { terhadap } \\
\text { teknik } \\
\text { evaluasi } \\
\text { kurikulum } \\
\text { yang } \\
\text { digunakan } \\
\text { oleh kepala } \\
\text { madrasah } \\
\text { pada saat } \\
\text { melakukan } \\
\text { balikan } \\
\text { pelaksanaan } \\
\text { /implement } \\
\text { asi } \\
\text { kurikulum } \\
\text { ini. } \\
\text { 5. Guru } \\
\text { memberika } \\
\text { n } \\
\text { tanggapan } \\
\text { positif }\end{array}$ & $\begin{array}{l}\text { mata } \\
\text { pelajaran } \\
\text { unggulan } \\
\text { dari } \\
\text { semua. } \\
\text { - }\end{array}$ \\
\hline
\end{tabular}

92 | Falasifa, Vol. 11 Nomor 1 Maret 2020 
Penguatan Manajemen Kurikulum Terintegrasi...

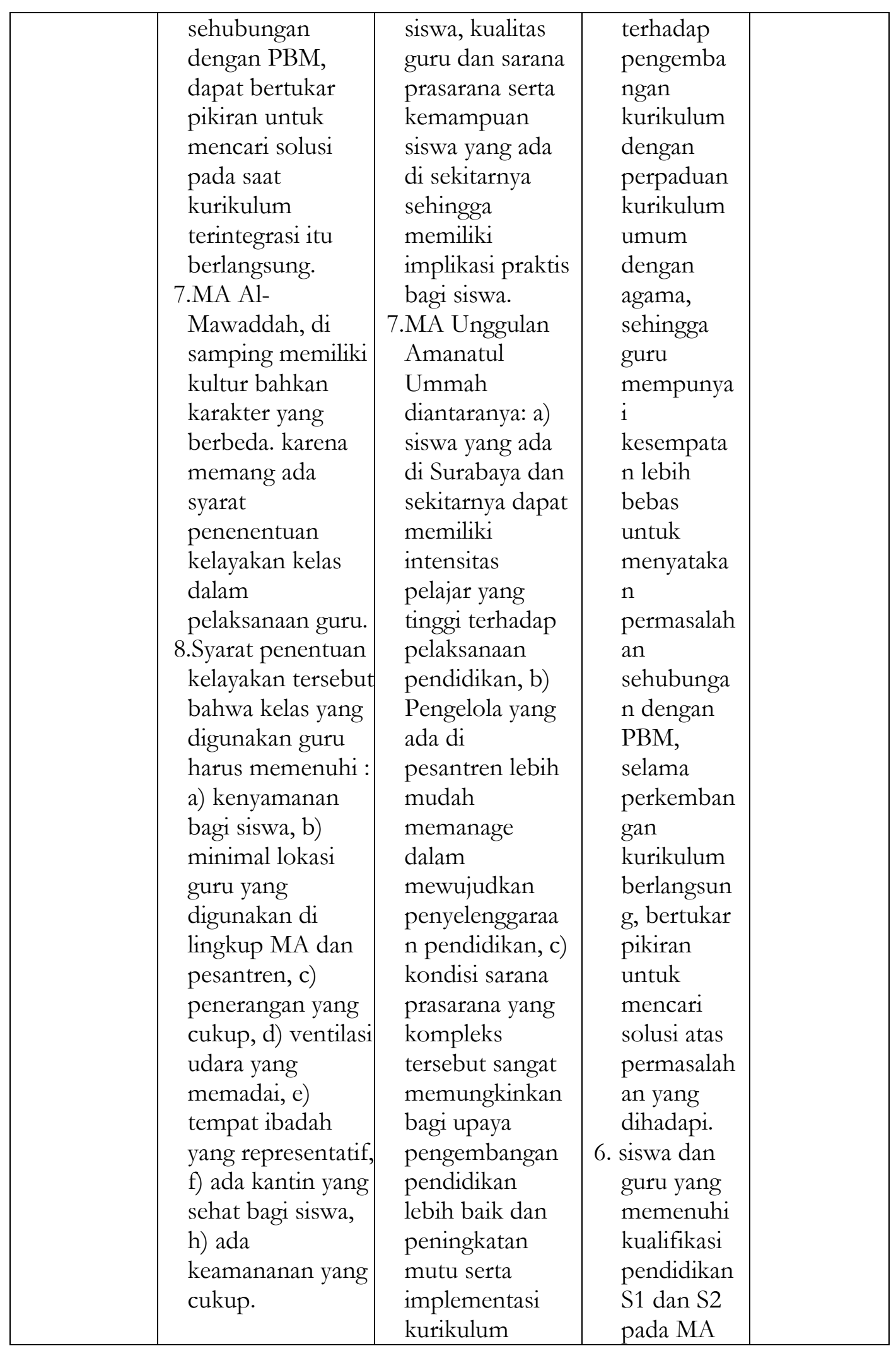

93 | Falasifa, Vol. 11 Nomor 1 Maret 2020 


\begin{tabular}{|c|c|c|c|c|}
\hline & & $\begin{array}{l}\text { terintegrasi di } \\
\text { madrasah } \\
\text { dengan } \\
\text { pesantren akan } \\
\text { lebih baik. }\end{array}$ & $\begin{array}{l}\text { Nurul, } \\
\text { sehingga } \\
\text { menjadi } \\
\text { bagian dari } \\
\text { motivasi } \\
\text { guru dan } \\
\text { siswa } \\
\text { untuk } \\
\text { melaksana } \\
\text { kan belajar } \\
\text { lebih } \\
\text { serius. } \\
\text { 7.Salah satu } \\
\text { kelemahan } \\
\text { yang ada di } \\
\text { MA Nurul } \\
\text { Jadid yakni } \\
\text { ada tenaga } \\
\text { guru yang } \\
\text { masih } \\
\text { kurang } \\
\text { dibandingk } \\
\text { an dengan } \\
\text { jumlah } \\
\text { siswa yang } \\
\text { ada di } \\
\text { madrasah } \\
\text { dan } \\
\text { pesantren } \\
\text { yang tidak } \\
\text { seimbang. }\end{array}$ & \\
\hline $\begin{array}{l}\text { Implementa } \\
\text { si } \\
\text { kurikulum } \\
\text { terintegrasi } \\
\text { antara } \\
\text { madrasah } \\
\text { dengan } \\
\text { pesantren }\end{array}$ & $\begin{array}{l}\text { 1. Tanggapan atau } \\
\text { reaksi guru MA } \\
\text { Al-mawaddah } \\
\text { terhadap } \\
\text { implementasi } \\
\text { kurikulum sebagai } \\
\text { berikut. }\end{array}$ & $\begin{array}{l}\text { 1.Tanggapan } \\
\text { postif guru } \\
\text { terhadap } \\
\text { implementasi } \\
\text { dan evaluasi } \\
\text { kurikulum } \\
\text { terintegrasi } \\
\text { dengan } \\
\text { menggunakan } \\
\text { pendekatan atau } \\
\text { umpan balik } \\
\text { dari para guru } \\
\text { sebagai berikut. }\end{array}$ & $\begin{array}{l}\text { 1. Tanggapan } \\
\text { atau reaksi } \\
\text { guru } \\
\text { terhadap } \\
\text { implementa } \\
\text { si dan } \\
\text { evaluasi } \\
\text { kurikulum } \\
\text { terintegrasi } \\
\text { dengan } \\
\text { menggunak } \\
\text { an } \\
\text { pendekatan } \\
\text { atau umpan }\end{array}$ & $\begin{array}{l}\text { 1. } \\
\text { Implem } \\
\text { entasi } \\
\text { kurikulu } \\
\text { m sudah } \\
\text { berjalan } \\
\text { dengan } \\
\text { baik, } \\
\text { hanya } \\
\text { saja } \\
\text { perlu } \\
\text { ada } \\
\text { respon } \\
\text { yang }\end{array}$ \\
\hline
\end{tabular}

94 | Falasifa, Vol. 11 Nomor 1 Maret 2020 
Penguatan Manajemen Kurikulum Terintegrasi...

\begin{tabular}{|c|c|c|c|}
\hline $\begin{array}{l}\text { 2. guru-guru } \\
\text { merespon positif } \\
\text { terhadap } \\
\text { implemetasi } \\
\text { kurikulum ini } \\
\text { sehingga apa yang } \\
\text { menjadi kendala } \\
\text { selama ini di } \\
\text { sekolah cepat di } \\
\text { respon oleh } \\
\text { kepala sekolah } \\
\text { sehingga } \\
\text { implementasi } \\
\text { selama ini akan } \\
\text { lebih baik, sangat } \\
\text { sesuai dengan } \\
\text { kondisi MA Al- } \\
\text { Mawaddah. } \\
\\
\text { implementasi } \\
\text { kurikulum sangat } \\
\text { membantu guru- } \\
\text { guru seperti } \\
\text { ketekunan, } \\
\text { ketelitian dan } \\
\text { kecermatan yang } \\
\text { ditunjukkan dapat } \\
\text { memotivasi PBM } \\
\text { untuk } \\
\text { melaksanakan } \\
\text { tugas dan } \\
\text { kewajiban sebagai } \\
\text { pendidik dapat } \\
\text { meningkat kinerja } \\
\text { kedepan. }\end{array}$ & $\begin{array}{l}\text { 2.pendekatan } \\
\text { kekeluargaan } \\
\text { yang dilakukan } \\
\text { kepala } \\
\text { madrasah } \\
\text { sangat } \\
\text { menyentuh, } \\
\text { guru merasa } \\
\text { saudara sendiri } \\
\text { pada saat } \\
\text { sosialisasi } \\
\text { kurikulum di } \\
\text { MA Unggulan } \\
\text { Amanatul } \\
\text { Ummah. Sikap } \\
\text { saling } \\
\text { menghargai, } \\
\text { toleransi, } \\
\text { semangat } \\
\text { kekeluargaan, } \\
\text { merupakan } \\
\text { kunci } \\
\text { keberhasilan } \\
\text { dalam } \\
\text { membangun } \\
\text { kemitraan } \\
\text { antara kepala } \\
\text { madrasah dan } \\
\text { guru-guru } \\
\text { dengan } \\
\text { semangat } \\
\text { kekeluargaan } \\
\text { membangun } \\
\text { situasi yang } \\
\text { kondusif, } \\
\text { menyenangkan } \\
\text { dan } \\
\text { membangkitkan } \\
\text { gairah kerja } \\
\text { guru dalam } \\
\text { menjalankan } \\
\text { tugas dengan } \\
\text { tulus. } \\
\text { 3.implementasi }\end{array}$ & $\begin{array}{l}\text { balik dari } \\
\text { para guru } \\
\text { sebagai } \\
\text { berikut. } \\
\text { 2. guru-guru } \\
\text { melakukan } \\
\text { pendekatan } \\
\text { secara } \\
\text { kekeluargaan } \\
\text { yang } \\
\text { dilakukan } \\
\text { kepala } \\
\text { madrasah } \\
\text { sangat } \\
\text { humanis, } \\
\text { guru merasa } \\
\text { lebih di } \\
\text { hargai } \\
\text { kompetensin } \\
\text { ya baik pada } \\
\text { saat } \\
\text { sosialisasi } \\
\text { kurikulum di } \\
\text { MA Nurul } \\
\text { Jadid. } \\
\text { 3.Sikap saling } \\
\text { menghargai, } \\
\text { toleransi, } \\
\text { semangat } \\
\text { kekeluargaa } \\
\text { n, } \\
\text { merupakan } \\
\text { kunci } \\
\text { keberhasilan } \\
\text { dalam } \\
\text { membangu } \\
\text { n situasi } \\
\text { yang } \\
\text { kondusif, } \\
\text { menyenang } \\
\text { kan dan } \\
\text { membangki } \\
\text { tkan gairah }\end{array}$ & $\begin{array}{l}\text { positif } \\
\text { dari } \\
\text { semua } \\
\text { pimpina } \\
\text { n dan } \\
\text { tim guru } \\
\text { serta } \\
\text { siswa } \\
\text { sebagai } \\
\text { obyek. } \\
\text { 2.sikap } \\
\text { kreatif } \\
\text { dan } \\
\text { inovasi } \\
\text { guru- } \\
\text { guru } \\
\text { dalam } \\
\text { pemberd } \\
\text { ayaan } \\
\text { sumber } \\
\text { daya } \\
\text { manusia } \\
\text { terhadap } \\
\text { kurikulu } \\
\text { m } \\
\text { terintegra } \\
\text { si dapat } \\
\text { berjalan } \\
\text { secara } \\
\text { efektif. }\end{array}$ \\
\hline
\end{tabular}

95 | Falasifa, Vol. 11 Nomor 1 Maret 2020 


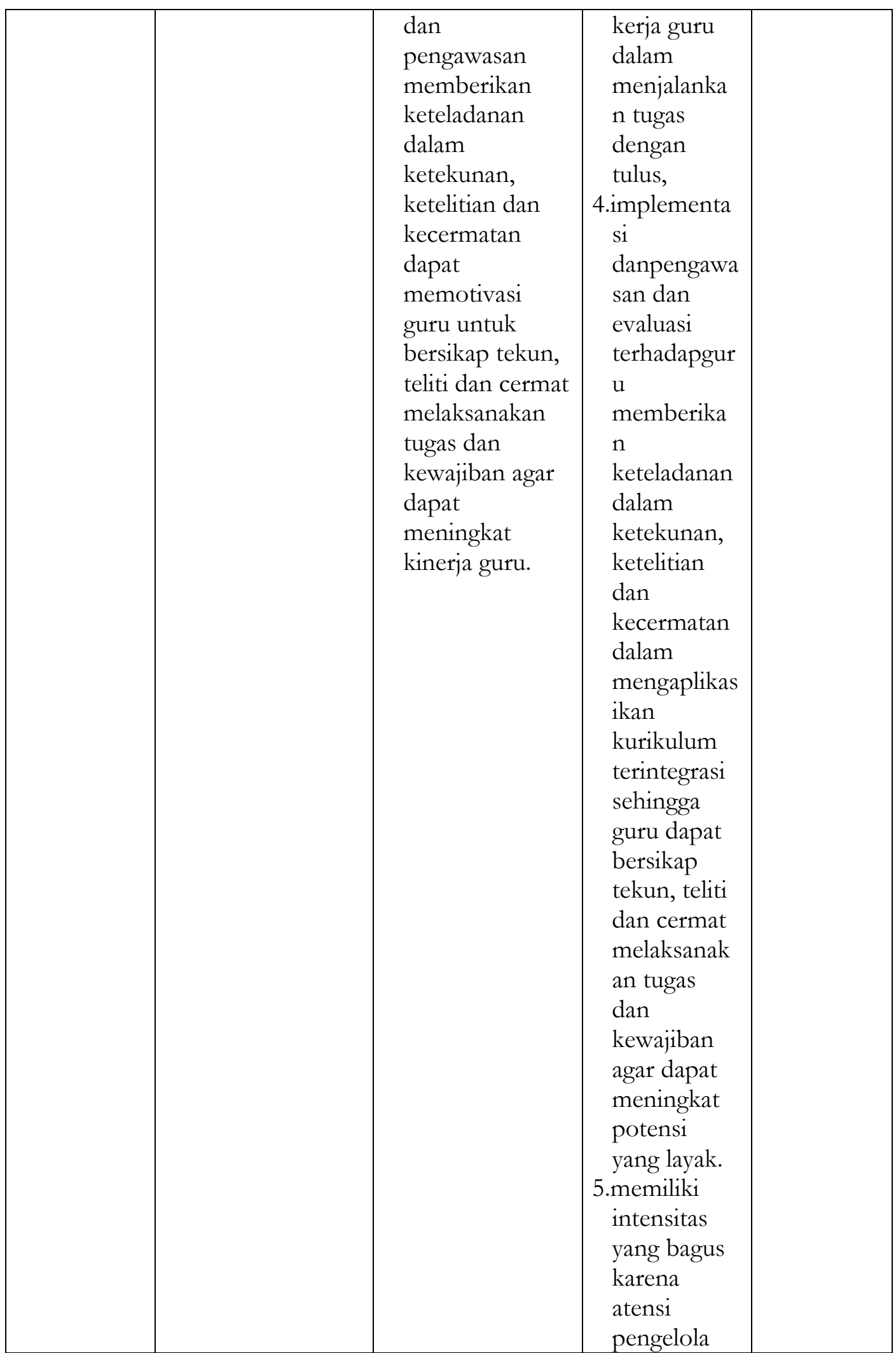

96 | Falasifa, Vol. 11 Nomor 1 Maret 2020 


\begin{tabular}{|c|c|c|c|c|}
\hline & & & $\begin{array}{l}\text { pondok } \\
\text { yang ada } \\
\text { dapat } \\
\text { dirasakan } \\
\text { representati } \\
\text { f bagi siswa } \\
\text { setempat. } \\
\text { 5. guru yang } \\
\text { hadir di MA } \\
\text { Nurul Jadid } \\
\text { juga } \\
\text { didukung } \\
\text { dengan } \\
\text { sejumlah } \\
\text { fasilitas } \\
\text { diantaranya } \\
\text { guru sudah } \\
\text { siap } \\
\text { sebelum } \\
\text { pelajaran } \\
\text { dimulai. }\end{array}$ & \\
\hline $\begin{array}{l}3 . \\
\text { evaluasi } \\
\text { kurikulum } \\
\text { terintegrasi } \\
\text { antara } \\
\text { madrasah } \\
\text { dengan } \\
\text { pesantren }\end{array}$ & $\begin{array}{l}\text { 1. Evaluasi } \\
\text { bertujuan untuk } \\
\text { memudahkan } \\
\text { komunikasikan } \\
\text { kepada peserta } \\
\text { didik. } \\
2 \text { memudahkan } \\
\text { guru memilih } \\
\text { dan menyusun } \\
\text { bahan. } \\
3 \text { memudahkan } \\
\text { guru } \\
\text { menentukan } \\
\text { kegiatan } \\
\text { pembelajaran } \\
\text { dan medianya, } \\
\text { dan. } \\
4 \text { memudahkan } \\
\text { guru } \\
\text { mengadakan } \\
\text { penilaian } \\
\text { (menentukan } \\
\text { bentuk tes, dan }\end{array}$ & $\begin{array}{l}\text { 1. Evaluasi dan } \\
\text { monitoring } \\
\text { yang telah } \\
\text { dilakukan } \\
\text { selama ini } \\
\text { tetap selalu } \\
\text { kondusif, } \\
\text { sehingga } \\
\text { pelaksanaa } \\
\text { pemalajar } \\
\text { mengajar } \\
\text { menjadi lebih } \\
\text { baik } \\
\text { 2. Pembagian } \\
\text { tugas kepada } \\
\text { semua guru } \\
\text { merata } \\
\text { 3. Sistem } \\
\text { kepercayaan } \\
\text { yang } \\
\text { dilakukan } \\
\text { penuh dengan } \\
\text { hati-hati } \\
\text { (cermat) }\end{array}$ & $\begin{array}{l}\text { 1.Evaluasi } \\
\text { kurikulum } \\
\text { terintegrasi } \\
\text { antara } \\
\text { madrasah } \\
\text { dengan } \\
\text { pesantren } \\
\text { dalam } \\
\text { memberika } \\
\text { n kontribusi } \\
\text { yang positif } \\
\text { bagi } \\
\text { kemajuan } \\
\text { MA Nurul } \\
\text { Jadid } \\
\text { sehingga } \\
\text { kedepan } \\
\text { dapat lebih } \\
\text { berkiprah } \\
\text { lagi. } \\
\text { 2.memberika } \\
\text { n } \\
\text { kepercayaan } \\
\text { penuh pula }\end{array}$ & $\begin{array}{l}\text { Fungsi } \\
\text { evaluasi: } \\
\text { pemanfaat } \\
\text { sumber } \\
\text { daya } \\
\text { manusia } \\
\text { perlu } \\
\text { mendapat } \\
\text { kan } \\
\text { perhatian } \\
\text { khusus, } \\
\text { Sarana dan } \\
\text { prasarana } \\
\text { yang } \\
\text { sudah } \\
\text { tersedia } \\
\text { dapat lebih } \\
\text { ditingkatka } \\
\text { n agar } \\
\text { proses } \\
\text { belajar } \\
\text { mengajar } \\
\text { terhadap } \\
\text { kurikulum }\end{array}$ \\
\hline
\end{tabular}

97 | Falasifa, Vol. 11 Nomor 1 Maret 2020 


\begin{tabular}{|c|c|c|c|c|}
\hline & $\begin{array}{l}\text { kriteria } \\
\text { pencapaiannya). }\end{array}$ & $\begin{array}{l}\text { dengan disertai } \\
\text { uraian tugas } \\
\text { yang jelas. }\end{array}$ & $\begin{array}{l}\text { pada guru } \\
\text { tetapi tetap } \\
\text { mengkoordi } \\
\text { nasi sesuai } \\
\text { dengan visi } \\
\text { misi } \\
\text { sekolah. }\end{array}$ & $\begin{array}{l}\text { yang telah } \\
\text { terintegrasi } \\
\text { dapat } \\
\text { sesuai } \\
\text { dengan } \\
\text { harapan } \\
\text { semua } \\
\text { kalangan. }\end{array}$ \\
\hline $\begin{array}{l}\text { 4.Implikasi } \\
\text { kurikulum } \\
\text { terintegrasi } \\
\text { antara } \\
\text { madrasah } \\
\text { dengan } \\
\text { pesantern }\end{array}$ & $\begin{array}{l}\text { 2.sikap tenang guru } \\
\text { pendiam dan } \\
\text { lemah lembut, } \\
\text { mempengaruhi } \\
\text { sikap guru pada } \\
\text { saat melakukan } \\
\text { proses PBM } \\
\text { dengan } \\
\text { mengaplikasikan } \\
\text { kurikulum setelah } \\
\text { di dalam kelas, } \\
\text { 3.guru bersikap } \\
\text { positif dengan } \\
\text { diamati dan } \\
\text { dinilai, terlebih } \\
\text { dahulu memulai } \\
\text { menyampaikan } \\
\text { hasil observasi } \\
\text { kurikulum } \\
\text { terintegrasi di } \\
\text { kelas } \\
\text { 4.guru sangat }\end{array}$ & $\begin{array}{l}\text { 1. Implikasi } \\
\text { kurikulum yang } \\
\text { ada MA } \\
\text { Unggulan } \\
\text { Amanatul } \\
\text { Ummah dapat } \\
\text { mempengaruhi } \\
\text { tanggapan atau } \\
\text { reaksi mereka } \\
\text { mereka } \\
\text { terhadap } \\
\text { pendekatan } \\
\text { unpan balik } \\
\text { serta } \\
\text { kepengawasan } \\
\text { kepala } \\
\text { madrasah. } \\
\text { 2. masih ada guru } \\
\text { yang belum siap } \\
\text { dengan } \\
\text { penerapan } \\
\text { kurikulum } \\
\text { terintegrasi ini, } \\
\text { sehingga solusi } \\
\text { yang baik } \\
\text { kepala sekolah } \\
\text { memberikan } \\
\text { altenatif yang } \\
\text { lain agar } \\
\text { sekolah tersebut } \\
\text { membawa } \\
\text { perubahan. }\end{array}$ & $\begin{array}{l}\text { 1.Implikasi } \\
\text { kurikulum } \\
\text { yang ada } \\
\text { MA Nurul } \\
\text { Jadid dapat } \\
\text { mempengar } \\
\text { uhi } \\
\text { tanggapan } \\
\text { atau reaksi } \\
\text { guru } \\
\text { terhadap } \\
\text { pendekatan } \\
\text { umpan balik } \\
\text { serta } \\
\text { kepengawas } \\
\text { an kepala } \\
\text { madrasah. } \\
\\
\text { 2.kurang } \\
\text { sosialisasi } \\
\text { kepada } \\
\text { guru-guru } \\
\text { tentang } \\
\text { bagaimana } \\
\text { tugas } \\
\text { tentang } \\
\text { kurikulum } \\
\text { ini }\end{array}$ & $\begin{array}{l}\text { Dari } \\
\text { semua } \\
\text { aspek } \\
\text { implikasi } \\
\text { kirikulum } \\
\text { terintegrasi } \\
\text {, maka } \\
\text { diperlukan } \\
\text { koordinasi } \\
\text { yang } \\
\text { intensif } \\
\text { bagi } \\
\text { kepala } \\
\text { sekolah, } \\
\text { serta } \\
\text { bagaimana } \\
\text { pemberda } \\
\text { yaan SDM } \\
\text { yang tepat } \\
\text { dengan } \\
\text { pendekata } \\
\text { n } \\
\text { kekeluarga } \\
\text { an yang } \\
\text { loyal dan } \\
\text { akrab. }\end{array}$ \\
\hline
\end{tabular}

98 | Falasifa, Vol. 11 Nomor 1 Maret 2020 


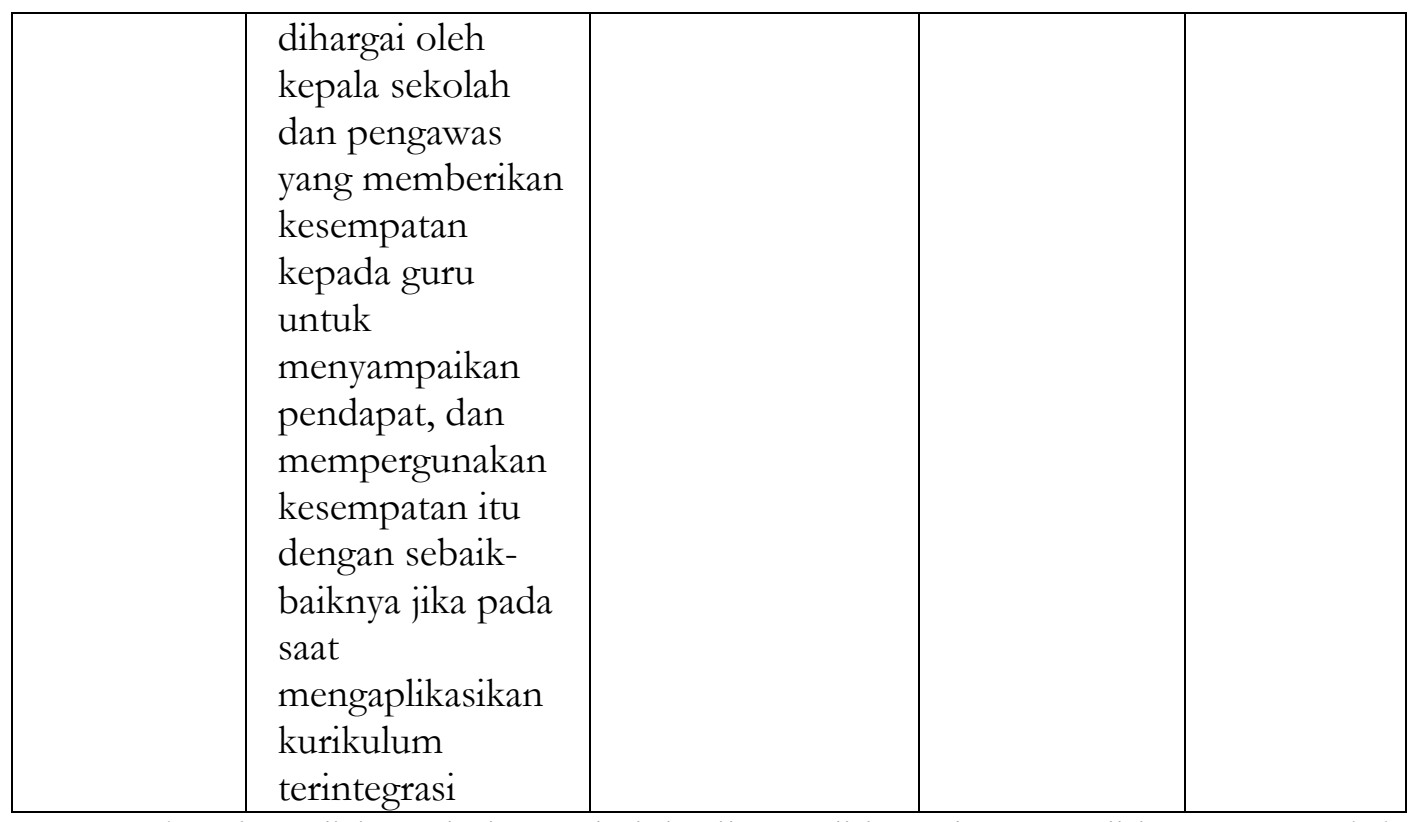

Sebagai analisis sederhana dari hasil penelitian, data penelitian menunjuk-kan bahwa ketiga lokasi tersebut antara guru dan siswa terdapat kerjasama dan fenomena masalah yang sangat sistematis dan kontinu. Kerjasama tersebut terletak pada konsep proses perencanaan kurikulum sudah mulai mendapat respon postif dari berbagai lembaga donatur. Untuk tataran implementasi kurikulum terintegrasi selalu mendapatkan perhatian dan dukungan yang positif dari beberapa pengelola lembaga tinggi baik yang ada di dalam negeri maupun luar negeri dengan kemajuan yang sangat signifikan. Fenomena tersebut merupakan hal yang wajar karena secara harfiah memiliki pengaruh pada biaya pendidikan anak-anak pesantren dengan berbagai macam prestasi yang dicapai selama ini maupun fasilitas pendukung pelaksanaan pendidikan, bentuk kerjasama dengan Kementerian agama termasuk sistem manajemen pendidikan yang digulirkan berjalan dengan sukses. Dengan demikian dari ketiga lokasi tersebut implementasi kurikulum terintegrasi antara madrasah dan pesantren dapat dinyatakan memiliki karakteristik yang berbeda serta peluang untuk meningkatkan mutu layanan terhadap siswa antara madrasah dan pesantren secara terprogram, bertahap, sistematis dan berkesinambungan sesuai dengan kearifan lokal masing-masing pengasuh pesantren.

Berdasarkan temuan lintas kasus di atas, dapat diformulasikan pada seluruhan fokus berikut paparannya. Berdasarkan mengembangkan sistem manajemen kurikulum terintegrasi antara madrasah dan pesantren secara institusional khususnya pondok pesantren yang berkualitas, maka dibutuhkan pendidik yang memiliki SDM yang handal. Implementasi 
kurikulum terintegrasi antara madrasah dengan pesantren sebuah upaya merubah visi menjadi aksi yang berorientasi pada ketercapaian standar pendidikan nasional dan internasional berdasarkan manajemen kurikulum terintegrasi. Manajemen kurikulum terintegrsai antara madarasah dengan pesantren akan tetap eksis, apabila di dukung oleh semua elemenyang ada, kerangka dasar dalam membangunsistem penyelenggaraan model kurikulum yang baru pada program Pendidikan madrasah aliyah. Untuk melaksanakan kurikulum terintegrasi pada semua kegiatan tersebut berjalan dengan baik, maka segenap komponen madrasah dengan pesantren tentu perlu mengenal, memahami prosedur baik terhadap perencanaan, pelaksanaan maupun monitoring dan evaluasi manajemen kurikulum terintegrasi.Perencanaan sistem kurikulum terintegrasi yang berkualitas, guru dan pengambilan peran secara sinergis diantara segenap civitas antara madrasah dengan pesantren, koordinasi akan bersinergi dengan baik. Perencanaan kurikulum terintegrasi perlu dilaksanakan dengan sungguh-sungguh mengingat sasaran pembangunan nasional adalah mencerdaskan bangsa pada program pendidikan antara madrasah dengan pesantren, dimana substansi program tersebut tidak lain adalah para siswa dan pendidik yang wajib memberikan dasar-dasar pendidikan secara kokoh kepada siswa.

Pengembangan keprofesian guru antara madrasah dengan pesantren akan berkesinambungan bagi guru dan siswa, maka cara efektif dalam meningkatkan pembelajaran lewat pembaharuan kurikulum.Tingkat kualitas kurikulum terintegrasi yang memiliki kualitas bagus, maka dalam hal ini sebagai pendukung obyektivitas siswa dan guru sebagai pelaku pendidikan antara madrasah dengan pesantren, sebagai "nurturant effect" dari sebuah model/sistem kurikulum terintergasi. Implementasi kurikulum tersebut menunjukkan nilai positif, ada kepuasan bagi guru dan siswa, maka sistem pembaharuan kurikulum yang ada akan lebih efektif sehingga layak untuk dikembangkan lebih lanjut secara berkesinambungan. Implementasi kurikulum terintegrasi antara madrasah dan pesantren dapat dicapai, apabila didasarkan pada objektivitas civitas akademika yang berkesinambungan.

Kurukulum terintegrasi sebuah perangkat pembelajaran yang efektif yang dapat digunakan untuk mengetahui kualitas dan pemahaman siswa dan guru dalam suatu kegiatan pembelajaran. Evaluasi manajemen kurikulum terintegrasi antara madarasah dengan pesantren untuk sementara ini merupakan sebuah alternatif yang layak digunakan sebagai kerangka dasar bagi sistem perangkat pembelajaran antara madrasah dengan pesantren. Evaluasi kurikulum 
terintegrasi antara madrasah dengan pesantren berdasarkan pembelajaran tersebut masih berkelanjutan dalam setiap lini, Sungguhpun demikian kelayakan penerapan sistem kurikulum yang ada tersebut perlu diperjuangkan dengan mengembangkan "komitmen" segenap komponen secara institusional. Implikasi manajemen kurikulum terintegrasi antara madrasah dengan pesantren dalam mengembangkan kualitas dan mutu sekolah, maka visi misi harus berdasarkan komitmen para kyai dan pengasuh pesantren yang akan berdampak positif disesuaikan dengan kebutuhan guru dan siswa. Implikasi kurikulum terintegrasi berimplementasi pada sistem kurikulum terintegrasi, maka berdasarkan kurikulum yang ada dapat diintegrasikan sesuai dengan kondisi madrasah dan pesantren, namun perlu disesuaikan dengan kebutuhan sekolah secara institusional. Guru merespon positif terhadap kurikulum terintegrasi sehingga proses belajar mengajar menjadi lebih kondusif.

\section{KESIMPULAN}

Bertolak dari temuan penelitian dan pembahasan, hasil penelitian dapat dirumuskan sebagai berikut. Implementasi kurikulum terintegrasi meliputi kegiatan menerapkan semua rancangan yang tercantum dalam kurikulum tertulis. Pada tahap ini, tujuan, program pendidikan, dan program pembelajaran yang telah direncanakan dilaksanakan dalam situasi pembelajaran. Model kurikulum terintergrasi serta implementasi kurikulum terintegrasi yang dapat dipilih, yaitu: (1) program pendidikan berbasis individu (individual educational program), (2) pembelajaran berbasis model (modelarized instruction), (3) pendidikan berbasis kompetensi (competency-based-education). Implementasi kurikulum dilakukan dengan model program pendidikan berbasis individu (individual educational program). Model kurikulum terintergrasi ini dipahami sebagai program pendidikan yang menempatkan peserta didik sebagai komponen utama, sementara hal lain di luar peserta didik hanya merupakan komponen yang bersifat komplementer. Bila model ini yang dipilih untuk implementasi kurikulum, maka guru harus menempatkan komponen buku ajar, media, strategi, dan lingkungan pembelajaran yang telah direncanakan sebagai komponen yang dapat memaksimalkan peseta didik di dalam proses pembelajaran. Untuk itu, guru harus menguji secara seksama relevansi buku paket, media, strategi, dan lingkungan pembelajaran dengan kebutuhan masing-masing peserta didik. Evaluasi merupakan kegiatan untuk menentukan pencapaian tujuan kurikulum dalam kegiatan belajar siswa (proses), perubahan perilaku siswa setelah mengikuti kegiatan belajar (hasil), dan 
keefektifan kurikulum dan pembelajaran. Kegiatan Model kurikulum terintergrasi memberikan informasi tentang perkembangan belajar peserta didik maupun keefektifan kurikulum dan pembelajaran sehingga dapat dibuat keputusan-keputusan pembelajaran dan pendidikan secara tepat.

Manajemen kurikulum terintegrasi pada madrasah di lingkungan pesantren sangat penting untuk dilakukan oleh guru dalam membantu peserta didik mencapai tujuan pembelajaran. manajemen kurikulum adalah suatu proses ketika peserta didik dalam tingkatan belajar, sangat kesulitan dengan cara mencapai tujuan tersebut melalui situasi belajar, serta penelaah keefektifan dan kebermaknaan metode yang ada.

\section{DAFTAR PUSTAKA}

Arikunto. 1990. Manajemen Penelitian. Jakarta: Rineka Cipta.

M. Afzalur Rahim, Toward a Theory of Managing Organizational Conflict, The International Journal of Conflict Management, 2002, Vol. 13, No. 3.

Dhofier, Z 1995. Tradition and Change in Indonesian Islamic Education. Jakarta: Office of Religious

Research and Development, Ministry of Religious Affairs of the Republica Indonesia.

Depag. RI. 1984/1985. Namadan Data Potensi Pondok Pesantren Selurub Indonesia. Jakarta: Dirjen Pembinaan Kelembagaan Agama Islam,

Departemen Agama RI. Al-Qur'an dan terjemahnya. Jakarta: Departemen Agama RI.

Depdiknas RI. 2001. Kurikulum Berbasis Kompetensi Mata Pelajaran PAI Jakarta: Badan Pusat Pengembangan Kurikulum.

Depdiknas. 2002. Kurikulum Berbasis Kompetensi. Jakarta:-Pusat Kurikulum Balitbank Depdiknas.

Depdiknas RI, 2002. Penyelenggaraan School Reform dalam Konteks MPMBS di SMU. Jakarta: Direktorat Pendidikan Menengah Umum, Dirjen Dikdasmen.

Departemen Pendidikan Nasioanal RI, 2003, Undang-Undang Republik Indonesia Nomor: 20 tabun 2003 tentang SISDIKNAS, Bandung, Citra Umbara

Departemen Agama RI, 2003, Pedoman Manajemen Berbasis Madrasah,Jakarta, proyek pemberdayaan Kelembagaan dan ketetelaksanaan pada Madrasah dan PAI pada sekolah umum tingkat dasar.

Departemen Agama RI, 2003, Pedoman pondok Pesantren, Jakarta

Departemen Agama RI, 2004, Pedoman Kegiatan Belajar Mengajar di pondok pesantren, Proyek peningkatan pendidikan luar sekolah pada pondok pesantren.

Departemen Agama RI, 2004, Desain pengembangan Madrasah, Ditjen Kelembagaan Agama Islam Departemen Agama RI.

Departemen Agama RI, 2004, Profil Pondok Pesantren Muadalah,Jakarta, proyek peninngkatan pondok pesantren

Departemen Agama RI, 2004, Sinergi madrasah dan pondok pesantren, suatu konsep pengembangan mutu madrasah, Jakarta. Proyek pemberdayaan Kelembagaan dan Ketatalasanaan pada Sekolah Umum Tingkat Menengah.

Departemen Agama RI, 2007. Pedoman Penyelenggaraan Diniyah Takmiliyah, Direktorat Pendidikan Diniyah dan Pondok Pesantren, Ditjen Pendis Depag, RI

102 | Falasifa, Vol. 11 Nomor 1 Maret 2020 
Departemen Agama RI, 2007. Pesantren Modern, Badan Litbang dan Diklat, Jakarta, Balai Penelitian dan Pengembangan Agama

Departemen Agama RI, 2008. Standar Kompetensi Lulusan (SKL) diniyahwustha, Jakarta; Direktorat Pendidikan Diniyah dan Pondok Pesantren, Dirjen Pendis.

Departemen Agama RI, 2008. Pedoman dan Implementasi Pengembangan Rencana Kerja Madrasah (RKM), MP3 Kanwil Departemen Agama Prov. Jatim

Departemen Agama RI, 2009. Panduan Teknis Pengembangan Kurikulum Madrasah Aliyah, Jakarta, Kemitraan Australia-Indonesia

Departemen Agama Republik Indonesia

Depertemen Agama RI, 2009. Pedoman dan Implimentasi pengembangan Kurikulum Tingkat Satuan

Pendidikan, Bidang Mapenda kanwil Depertemen Agama Prov. Jatim.

Yasmadi, Modernisasi Pesantren (Kritik Nurcholis Madjid Terhadap Pendidikan Islam Tradisional). Jakarta: Ciputat Press, 2002.

Kementerian Sekretaris Negara. 1974. Undang-undang No. 5 Tahun 1974.

Rasiyo 2005. Kebijakan Desentralisasi Manajemen Pendidikan Pada Era Otonomi Daerah,Surabaya:Program Doktor Ilmu Adminitrasi,Universitas 17 Agustus 1945.

Bafadah Ibrahim, Peningkatan Manajemen Mutu Sekolah Dasar: dari sentralisasai menuji desentralisasai, Jakarta, Bumi Aksara, 2003.

Anwar, Qomari. dan Syaiful, Sagala. 2004. Profesi Jabatan Kependidikan dan Guru Sebagai Upaya Menjamin Kualitas Pembelajaran. Jakarta: Uhamka Press.

Peraturan Menteri Pendidikan Nasional Republik Indonesia Nomor 22 tahun 2006 tentangStandar Isi untuk. Satuan Pendidikan Dasar dan Menengah, Kanwil Departemen Agama Provinsi Jawa Timur.

Nasution, 1996. MetodePenelitianNaturalistik Kualitatif. Bandung, Tarsito.

Miles, B. \& Huberman, 1992 Analisis Data Kualitatf. (Terjemahan Tjetjep Rohendi Rohidi). Jakarta: Penerbit Universitas Indonesia, 1992.

Guba, E.G \& Lincoln Y.S, 1981, Effektif Evaluation. Improving The Usefulness Of Evaluations Result Through Responsive And Naturalistic Approaches. Jassey-Bass Inc. Publisher. 